the principal stresses may he found. If it is required to find the magnitude of each principal stress separately, a further technique is required which was not considered in this paper.

In order that these patterns may be photographed successfully, it is necessary to use a suitable polariscope. An instrument which had been found satisfactory was demonstrated, and various points in its design were discussed. With this instrument photographs had been obtained with very short exposures. Consideration was also given to the best photographic materials for this type of work.

A recent development, particularly in Great Britain, has been the combination of photo-elastic stress analysis with the technique of high-speed photography for recording sudden dynamic stresses, carried out at the Research Laboratories of Kodak Ltd. Two methods are available : in the first, a brilliant flash of very short duration is used to record a very rapidly moving phenomenon, and a photograph was shown taken in natural colour with the 'Kodatron' Speedlamp at an exposure of about $1 / 10,000$ sec. In the second method, a cine-film, taken at a very high rate, is then projected at a normal rate so that the action is greatly slowed down. Such a film, believed to be the first of its type taken in natural colour, was shown; in this, the exposures were taken at the rate of 1,000 per second. It showed the stresses found in the chair holding a railway line to the sleeper, and a 'still' from the film is shown in Fig. 2.

Prof. Bogue said, in closing the meeting, the programme must surely have demonstrated that photography is a scientific instrument capable of many and varied applications.

\title{
U.S. NATIONAL ACADEMY OF SCIENCES
}

\section{ANNUAL MEETING}

A $T$. the annual meeting of the U.S. National Academy of Sciences held on April 27, the following officers and new members were elected :

President : Dr. Frank B. Jewett, re-elected for a further term of four years. Home Secretary: Dr. F. E. Wright, refelected for a further term of four years. Members of Council: W. Mansfield Clark, De Lamar professor of physiological chemistry, Johns Hopkins Medical School (re-elected); Walter R. Miles, professor of psychology, Yale University School of Medicine (succeeding Prof. Oswald Veblen).

Foreign Associates : Alfonso Caso, Instituto Nacional de Antropologia e Historia, Mexico City; Sir Harold Spencer Jones, Astronomer Royal, Royal Observatory, Greenwich ; Dr. R. V. Southwell, rector of the Imperial College of Science and Technology, London; Prof. C. E. Spearman, emeritus professor of psychology in the University of London; Sir D'Arcy Thompson, professor of natural history in the University of St. Andrews; Dr. H. J. van der Bijl, chancellor of the University of Pretoria.

New Members of the Academy: L. H. Adams, Geophysical Laboratory, Carnegie Institution of Washington; Dr. A. Adrian Albert, assistant professor of mathematics, University of Chicago ; Prof. J. W. Beams, professor of physics, University of Virginia; Prof. A. F. Buddington, professor of geology, Princeton University; Dr. Leonard Carmichael, president of Tufts College, Medford, Massachusetts; Prof. W. H. Chandler, professor of pomology, University of California, Los Angeles; Prof. E. J. Cohn, professor of biochemistry, Harvard Medical School; Prof. J. N. Couch, professor of botany, University of North Carolina; Prof. Th. Dobzhansky, Columbia University ; Prof. Løe A. DuBridge, professor and chairman of the Department of Physics, University of Rochester; Dr. L. C. Dunn, professor of zoology, Columbia University ; Prof. Wallace O. Fenn, professor of physiology, University of Rochester ; Dr. Paul D. Foote, director of research and executive vice-president, Gulf Research and $\mathrm{De}_{\mathrm{P}}$ velopment Company, Pittsburgh, Pa.; Prof. L. P. Hammett, professor of chemistry, Columbia University ; Prof. William V. Houston, professor of physics, California Institute of Technology, Pasadena, California ; Prof. Walter P. Kelley, professor of agri- cultural chemistry, Citrus Experiment Station, Riverside, California; Dr. Warfield T. Longcope, pro. fessor of medicine, Johns Hopkins University; Dr. E. K. Marshall, jun., professor of pharmacology and experimental therapeutics, Johns Hopkins Medical School ; Dr. L. Michaelis, Rockefeller Institute for Medical Research, New York; Dr. W. Albert Noyes, jun., professor of physical chemistry, University of Rochester ; Prof. O. H. Robertson, professor and head of the Department of Medicine, University of Chicago ; C. G. Rossby, University of Chicago ; Prof. Calvin P. Stone, professor of psychology, Stanford University; Dr. C. V. Taylor, professor of zoology, Stanford University ; Dr. H. B. Vickery, in charge of Biochemical Laboratory, Connecticut Agricultural Experiment Station, New Haven, Connecticut; Dr. V. K. Zworykin, director of the Electronic Research Laboratory, RCA Manufacturing Company, Camden, N.J.

\section{Presentation of Medals}

The following five gold medals were presented :

Henry Draper Medal for 1942, to Ira Sprague Bowen, of the California Institute of Technology, Pasadena, California, in recognition of his contributions to astronomical physics; more especially his researches on the spectra and chemical composition of the gaseous nebulæ. Best known and one of Dr. Bowen's most brilliant accomplishments was his discovery of the nature of 'nebulium' lines, a most difficult problem solved by him after the ablest spectroscopists had struggled with it for three quarters of a century and had failed. This discovery and the results of his subsequent researches yielding the identification of numerous other forbidden lines in nebular and stellar spectra constitute some of the most important advances in astrophysics within recent years.

The Draper Medal is provided by the income from a trust fund given to the Acaderny in 1883 by Mrs. Henry Draper in memory of her husband, a former member of the Academy. It is awarded for investigations in astronomical physics. The present award is the twenty-sixth.

Agassiz Medal for 1942, with accompanying 
honorarium of 300 dollars, to Columbus O'Donnel Iselin, II, director of the Woods Hole Oceanographic Institution, Woods Hole, Massachusetts, in recognition of his studies of the Gulf Stream system, for his leadership in the development of a general programme of the physical oceanography of the North Atlantic, and for his distinguished direction of the activities of the Woods Hole Oceanographic Institution, both in peace and in time of war.

The Agassiz Medal is provided by the income from a trust fund given to the Academy by Sir John Murray in 1911 in honour of Alexander Agassiz. It is awarded for contributions in the science of oceanography. The present award is the nineteenth.

Daniel Giraud Elliot Medal for 1935, with accompanying honorarium of 200 dollars, to Edwin $\mathrm{H}$. Colbert, of the American Museum of Natural History, New York City, in recognition of his "Siwalik Mammals in the American Museum of Natural History", published in the Transactions of the American Philosophical Society in October 1935.

Daniel Giraud Elliot Medal for 1936, with accompanying honorarium of 200 dollars, to Robert Cushman Murphy, of the American Museum of Natural History, New York City, in recognition of his "Oceanic Birds of South America", published in two volumes in 1936 .

The Elliot Medals are provided by the income from a trust fund given to the Academy by Margaret Henderson Elliot in honour of her father, Daniel Giraud Elliot, in 1917. The award to Dr. Colbert is the eighteenth Elliot Medal to be presented by the Academy; and that to Dr. Murphy is the nineteenth. The deed of gift of the Elliot Fund calls for an annual award for the most meritorious work published during that year upon some branch of zoology or palæontology.

John J. Carty Medal and Award for the Advancement of Science for 1943 (medal and 4,000 dollars), to Edwin Grant Conklin, of Princeton University, Princeton, New Jersey, in recognition of his services to science as zoologist, cytologist and embryolngist; philosopher, teacher and man of science; student of life and of growth from lowliest beginnings to highest consummation.

The Carty award is provided by the income from a trust fund given to the Academy in 1930 by the American Telephone and Telegraph Company, in honour of John J. Carty, a former vice-president of that company, who was a member of the Academy. The medal and monetary award, made not oftener than once in every two years, are awarded to an individual for noteworthy and distinguished accom. plishments in any field of science coming within the scope of the charter of the Academy. The present award is the fourth to be presented by the Academy.

\section{NEWS and VIEWS}

\section{Rothamsted Experimental Station: New Director}

IN a few months time, Rothamsted, the world's oldest and most famous agricultural research station, will celebrate the centenary of its foundation and another period of useful activity will begin, though under a new director, Dr. William Gammie Ogg. Dr. Ogg is the son of a farmer and is known to farm successfully himself, so that he may be described as close to the soil. It is known that in future Rotham. sted will concentrate more closely on soil problems, extending what has been discovered at Harpenden and Woburn to other types of soil, so that the new director is appropriately a soil specialist. Dr. Ogg studied at Aberdeen under Japp, began research in agriculture there, but on the outbreak of war in 1914 became a chemist in the explosives industry, ending up as chief chemist and works manager at Greetland. After 1918 he came back to agricultural research and spent a year in Canada and the United States. On his return he went as a research student to Christ's College, Cambridge, and for four years he was technical adviser to Messrs. Chivers.

In 1924 the soil claimed Dr. Ogg once more, and he was appointed advisory officer in soils at the Edin. burgh and East of Scotland College of Agriculture, where he stayed for six years studying soils in various parts of the world. When the Macaulay Institute for Soil Research was founded in 1930 at Craigiebuckler, Aberdeen, he became the first director. In the ensuing decade Dr. Ogg has gathered round him a band of young and keen workers, so that in a short time the Institute has achieved considerable fame in connexion with the many problems of soil survey. The work has involved the development of a tech- nique of quick analysis of the minor constituents of the soil by modern physical methods. His services have been extensively used by the Agricultural Research Council, and he has published quite widely. Dr. Ogg will bring to Rothamsted a full knowledge of the soil and its many problems; he is a proved administrator and leader.

\section{Institute of Fuel : Melchett Medal}

The Melchett Medal for 1943 of the Institute of Fuel has been awarded to Dr. E. S. Grumell. This medal is the highest award in the gift of the Institute of Fuel and is being presented to Dr. Grumell in recognition of the outstanding work tending to the economical use of fuel which he has done over a long period. Dr. Grumell has, for many years, been head of the coal research laboratories of the Imperial Chemical Industries, Ltd., and the research and experimental work carried out by him, having been published for the benefit of the community as well as for that of his company, has resulted in improving the design of many combustion appliances and, consequently, in the saving of large quantities of fuel. In addition, Dr. Grumell was appointed chairman of the Fuel Efficiency Committee set up by the Mines Department and later carried on under the Ministry of Fuel and Power. The work of that Committes has undoubtedly contributed very largely to the more economical use of fuel in Great Britain, thus enabling our output of coal to meet the essential demands of both industrial and domestic requirements. The medal will be presented at the annual conference of the Institute of Fuel to be held in October next. 